\title{
THE EFFECTIVENESS OF JIGSAW LEARNING STRATEGY TO IMPROVE STUDENTS' READING ABILITY
}

\author{
Kurniawan Yudhi N (1) \\ Khosiatul Fitri (2)
}

\begin{abstract}
This research was an attempt to investigate the use of Jigsaw learning Strategy in term of improving students' reading ability. This six month project was conducted to Senior-high school students around Semarang. In order to get to know the impact of this program, this research required two classes designed as the class of experiment and the class of control. Each class would have its roles in this research. As the project was completely done, it was observed that the mean score of the posttest in the class of experiment (85.4412) was higher than that of the class of control (67.95). Of referring to the data, this was concluded that this learning strategy was positively effective to improve students' learning performance in reading.
\end{abstract}

Keywords: Jigsaw learning strategy, reading ability, experimental research

\section{INTRODUCTION}

As a social being, human needs to communicate one another. Therefore, communication is essentially needed. Communication will not happen without interaction. When they are interacting, they need language. Therefore, language is perceived to be important. By using language, they may express feelings, ideas, thoughts and attitudes happen within their daily life. In Indonesia, English is taught as a foreign language. The process of learning and teaching in this country officially starts from junior high school level and will end up into university level. The purpose of this teaching is to help Indonesian students learn English and improve their English skills, such as listening, speaking, writing and reading. Reading is perceived to be an important skill considering the avail comprehension of abundant information in the form written text. Reading is a process of building and understanding written text which involves activity that can be done everywhere. Furthermore, for Indonesian secondary education, reading is one of the aspects to be tested in the national examination.

For some reasons, it is found to be difficult for students. In common, problems of reading for senior high school students is identified due to some factors, some of them lack of experience and practices which result in inability to fast understand 
and conclude text they are reading. These kinds of issues were identified to contribute problems to learners, especially high school learners, when they are working on English tests. Appropriate instructional technique tailored to the students' need can be one of the alternatives to reduce the complexity within the process of teaching and learning. There are various types of teaching strategies, teachers may apply in the classrooms; role-play, problem based instruction, change of pairs, group investigation, students achievement division, jigsaw etc. Jigsaw is one of cooperative learning activities that puts forward high responsibility to the students to be successful in learning. By far jigsaw learning strategy is commonly adopted to teach reading. Being used properly, these may give benefit to the learners in term of making them able to express and to communicate with the others through grouping, in addition, this will also provide them with chance to discuss the topic given by the teacher, and explain it to other groups. Jigsaw learning strategy highly places emphasis on cooperation and responsibility within the group activities. The success of each group depends on the active participation of each in completing their task. This research is designed in order to investigate the use of Jigsaw learning strategy in term of improving students' reading ability.

\section{What is Cooperative Learning?}

Cooperative learning is a learning method designed to help learners improve their understanding and attitude adjusted with the real life in the society (Solihatin and Raharjo, 2007: 5). Cooperative learning is a teaching method designed with the goal to improve learners' academic skills, social skill, including interpersonal skill (Riyanto, 2010: 267). Cooperative learning is a teaching method where learners study by making small groups that have different abilities based on high, medium and low capability of learners. In finishing assignment, every group member is expected to help each other and try to comprehend the material resources (Alma and Hurriyati, 2008: 368). In summary, cooperative learning can best be understood as a teaching method required learners learn cooperatively work in the assigned tasks. In the process of learning, learners will be divided into groups and every group member will hold accountability to help their friends achieve the goal.

\section{What is Jigsaw Learning Strategy?}

Jigsaw is a cooperative learning strategy that has been used for over thirty years. Jigsaw is a kind of strategy that allows learners work cooperatively and help each other in dealing with new learning materials. Within the interaction in the 
group, they will have particular active role to teach other members in the group on the materials they have studied. During its implementation, Jigsaw will require at least five to six participants in one group (Brisk and Harrington, 2000: 83). Further, referring to its characteristics, this strategy belongs to cooperative learning that in fact has been studied by researchers and teachers in classes of different levels and subjects. Each student involved, in this case, will have unique information and be an essential piece for their group as each of them will have significant role to succeed the learning in their group on the topic whole group is studying (Mengduo and Xiaololing, 2010: 113). Adams (2013: 65) says "the unique characteristic of jigsaw is that students are given portion of the total learning task to master than teach that segment to the other members of their team. Until all of the pieces of the learning "puzzle" are in place, meaningful learning cannot occur; hence, the name is jigsaw". Of the explanation above, this might be synthesized that this strategy is way to help teachers reach their teaching goals where the students are assigned to study in groups (four to six members). Each of whom has personal task to set up to and needs to disseminate the finding to the other members in their group of origin.

\section{METHODS}

Research design is the way used in conducting a research. In order to succeed doing this, this research has to involve systematic and objective analysis and recording of controlled observations that may lead to the development of generalizations, principles, or theories, resulting in prediction and possibly ultimate control of events (Cohen et.al, 2006: 6). Having a look at the characteristics of this research, this research belongs to experimental research design to which it is intended to look for the cause of relationship between experimental group and control group (Arikunto, 2006:3). Seventy-one students divided in two different classes were used as the sample of the research. These samples were selected purposively by referring to particular characteristics set up initially. There were several steps required in order to collect the data, including checking validity and reliability of the instruments, doing pre-comprehensive test in the beginning before the class started, conducting the training, and administering post-comprehensive test after the training ended. As all steps mentioned had been completed, it was then proceeded with statistically calculating the data before being presented. All questions used in the test were multiple choices. Pretest and posttest questions 
were similar in all aspect (design, level of questions, number of questions and time allotment), but content presented in the tests, meaning that the students would not do the tests with the same questions.

\section{FINDINGS}

Progress report of experimental class

a. Pretest

This test was administered in September 27th 2014 . The aim of the test was to measure learners' initial reading ability before the training.

Table 1 Pretest result in experimental class

\begin{tabular}{cc}
\hline Score & Number of Students \\
\hline $81-100$ & 0 \\
\hline $61-80$ & 8 Students \\
\hline $41-60$ & 26 Students \\
\hline $21-40$ & 0 \\
\hline $0-20$ & 0 \\
\hline Total & 34 \\
\hline
\end{tabular}

b. Posttest

This test was performed in April 3 ${ }^{\text {rd }}, 2015$ after the training ended. The purpose of this test was to measure learners' learning progress after the training.

Table 2 The Posttest result in experimental class

\begin{tabular}{cc}
\hline Score & Number of Students \\
\hline $81-100$ & 4 Students \\
\hline $61-80$ & 23 Students \\
\hline $41-60$ & 7 Students \\
\hline $21-40$ & 0 \\
\hline $0-20$ & 0 \\
\hline Total & 34 \\
\hline
\end{tabular}

Progress report of control class

a. Pretest

This test was held in September 27th 2014 . The goal of the test was to investigate students' initial reading achievement. For the benefit of the research, the same questions were addressed to the learners in the class of control. 
Table 3 Pretest result in control class

\begin{tabular}{cc}
\hline Score & $\begin{array}{c}\text { Number of } \\
\text { Students }\end{array}$ \\
\hline $81-100$ & 0 \\
\hline $61-80$ & 17 \\
\hline $41-60$ & 20 \\
\hline $21-40$ & 0 \\
\hline $0-20$ & 0 \\
\hline Total & 37 \\
\hline
\end{tabular}

\section{b. Posttest}

This test was held in April, 3rd 2014. The testing date was selected by referring to the training period held in the class of experiment. The same questions were made similar to those of experimental class in order to avoid bias. This test was important to do in order to check the learning progress of the students as well as to gain data required for conducting final calculation on the testing results between those two groups, which is for the benefit to this research.

Table 4 Posttest result in control class

\begin{tabular}{cc}
\hline Score & $\begin{array}{c}\text { Number of } \\
\text { Students }\end{array}$ \\
\hline $81-100$ & 0 \\
\hline $61-80$ & 26 \\
\hline $41-60$ & 11 \\
\hline $21-40$ & 0 \\
\hline $0-20$ & 0 \\
\hline Total & 37 \\
\hline
\end{tabular}

Comparison of reading achievement scores in the class of control and experiment

After getting the result of control class and experimental class, the data were then compared in order to generate understanding. See the table below for detail:

Table 5 Comparison of reading achievement pretest scores of experimental and control class

\begin{tabular}{|c|c|c|c|c|c|c|c|}
\hline \multirow[t]{2}{*}{ Group } & \multirow[t]{2}{*}{$\mathrm{N}$} & \multirow[t]{2}{*}{ Mean } & \multirow{2}{*}{$\begin{array}{c}\text { Std. } \\
\text { Deviatio } \\
\mathrm{n}\end{array}$} & \multicolumn{2}{|c|}{$\begin{array}{c}\text { Levene's Test for } \\
\text { Equality of Variances }\end{array}$} & \multicolumn{2}{|c|}{$\begin{array}{l}\text { T-test for Equality of } \\
\text { Means }\end{array}$} \\
\hline & & & & $\mathrm{F}$ & Sig. & $\begin{array}{c}\text { Sig. } \\
\text { (2-tailed) }\end{array}$ & $\begin{array}{c}\text { Mean } \\
\text { difference }\end{array}$ \\
\hline Control & 37 & 60.24 & 7.946 & \multirow[b]{2}{*}{3.103} & \multirow[b]{2}{*}{.083} & \multirow[b]{2}{*}{.269} & \multirow[b]{2}{*}{1.890} \\
\hline $\begin{array}{l}\text { Experim } \\
\text { ental }\end{array}$ & 34 & 58.35 & 6.134 & & & & \\
\hline
\end{tabular}

Sig. (2-tailed) $\leq 0.05=$ Significance difference 
In the table $5, \mathrm{~N}$ reflects the number of students in those two classes, control (37) and experimental class (34). The mean score of pre-test for the control class was 60.24, while the mean score in the experimental class was 58.35. The standard deviation of the two classes was different, control class (7.946) and experimental class (6.134). Sig.(2-tailed) was found to be .269 and the mean difference was 1.890. Sig was .083. From the Leven's Test for Equality of Variances indicates homogeneity $\mathrm{F}=3.103$. Overseeing the table above, it is understood that those two selected classes departed at the same level of proficiency.

Table 6 Comparison of reading achievement posttest scores of experimental and control class

\begin{tabular}{|c|c|c|c|c|c|c|c|}
\hline \multirow[b]{2}{*}{ Group } & \multirow[b]{2}{*}{$\mathrm{N}$} & \multirow[b]{2}{*}{ Mean } & \multirow[b]{2}{*}{$\begin{array}{c}\text { Std. } \\
\text { Deviation }\end{array}$} & \multicolumn{2}{|c|}{$\begin{array}{c}\text { Levene's Test for } \\
\text { Equality of Variances }\end{array}$} & \multicolumn{2}{|c|}{ T-test for Equality of Means } \\
\hline & & & & $\mathrm{F}$ & Sig. & $\begin{array}{l}\text { Sig. }(2- \\
\text { tailed) }\end{array}$ & $\begin{array}{c}\text { Mean } \\
\text { difference }\end{array}$ \\
\hline Control & 37 & 67.95 & 7.472 & & & & \\
\hline $\begin{array}{l}\text { Experi } \\
\text { mental }\end{array}$ & 34 & 71.68 & 8.142 & .641 & .426 & .048 & -3.731 \\
\hline
\end{tabular}

Sig. (2-tailed) $\leq 0.05=$ Significance difference

As the table 6 shows that, $\mathrm{N}$ reflects the number of students in those two classes, control (37) and experimental class (34). The mean score of post-test was 67.95 for control class, while the mean score in the experimental class was 71.68 . The standard deviation of the two classes was different, control class (7.472) and experimental class (8.142). Sig. (2-tailed) was observed to be .048 and the mean difference was -3.731. Sig was .426. From the Leven's Test for Equality of Variances indicates homogeneity $\mathrm{F}=.641$. From the table above, the results show that there is significance difference between the mean scores of experimental and control class and it is noticed that the training addressed to experimental class has gained higher impact on the students' reading achievement when compared to that of control class.

Further to this, in order to check the progress before and after the training, analysis was also performed by comparing pretest and posttest score either in the class of experiment or control. Below are details of the calculation results: 
Table 7 Comparison of pre and posttest result of reading achievement test scores of control class

\begin{tabular}{|c|c|c|c|c|c|c|c|}
\hline \multirow[t]{2}{*}{ Group } & \multirow[t]{2}{*}{$\mathrm{N}$} & \multirow[t]{2}{*}{ Mean } & \multirow[t]{2}{*}{$\begin{array}{l}\text { Std. } \\
\text { Deviation }\end{array}$} & \multicolumn{2}{|c|}{$\begin{array}{l}\text { Levene's } \\
\text { Test for } \\
\text { Equality of } \\
\text { Variances }\end{array}$} & \multicolumn{2}{|c|}{$\begin{array}{c}\text { T-test for } \\
\text { Equality of Means }\end{array}$} \\
\hline & & & & $\mathrm{F}$ & Sig. & $\begin{array}{c}\text { Sig. } \\
\text { (2-tailed) }\end{array}$ & $\begin{array}{c}\text { Mean } \\
\text { Difference }\end{array}$ \\
\hline Pre-Test & 37 & 60.24 & 7.946 & .2 & & & \\
\hline Post-Test & 37 & 67.95 & 7.472 & $\begin{array}{l}9 \\
7\end{array}$ & .587 & .000 & -7.703 \\
\hline
\end{tabular}

Sig. (2-tailed) $\leq 0.05$ = Significance difference

The table 7 shows results of two different tests, pre-test and post-test. Each test was participated by 37 students. The mean of pre-test in control class was 60.24 and post-test in control class was 67.95. The standard deviation of pre-test was 7.946 and standard deviation of pos-test was 7.472. Sig. (2-tailed) was 0.000 and mean difference was -7.703. Sig was 0.587. From the Leven's Test for Equality of Variances indicates homogeneity $\mathrm{F}=0.297$. Of referring to the statistical calculation result, it is observed that there is significant difference between the mean scores of pretest result of the control class when it is compared to their reading comprehension achievement posttest scores.

Table 8 Comparison of pre and posttest result of reading achievement test scores of experimental class

\begin{tabular}{|c|c|c|c|c|c|c|c|}
\hline \multirow[t]{2}{*}{ Group } & \multirow[t]{2}{*}{$\mathrm{N}$} & \multirow[t]{2}{*}{ Mean } & \multirow{2}{*}{$\begin{array}{c}\text { Std. } \\
\text { Deviation }\end{array}$} & \multicolumn{2}{|c|}{$\begin{array}{l}\text { Levene's Test for } \\
\text { Equality of } \\
\text { Variances } \\
\end{array}$} & \multicolumn{2}{|c|}{$\begin{array}{c}\text { T-test for } \\
\text { Equalityof Means }\end{array}$} \\
\hline & & & & $\mathrm{F}$ & Sig. & $\begin{array}{c}\text { Sig. } \\
\text { (2-tailed) }\end{array}$ & $\begin{array}{c}\text { Mean } \\
\text { Difference }\end{array}$ \\
\hline $\begin{array}{l}\text { Pre- } \\
\text { Test }\end{array}$ & 34 & 58.35 & 6.134 & \multirow{2}{*}{4.150} & \multirow{2}{*}{.046} & \multirow{2}{*}{.000} & \multirow{2}{*}{-13.324} \\
\hline $\begin{array}{l}\text { Post- } \\
\text { Test }\end{array}$ & 34 & 71.68 & 8.142 & & & & \\
\hline
\end{tabular}

Sig. (2-tailed) $\leq 0.05$ = Significance difference

The table 9 shows the statistical calculation results of two different kinds of tests, pre-test and post-test. Every test had 36 students. Referring to the table the mean of pre-test in experimental class was found to be 58.35, while in the post-test, it was 71.68. The standard deviation of pre-test was 6.134 and standard deviation of pos-test was 8.142. Sig. (2-tailed was .000 and mean difference was -13.324. Sig was .046. From the Leven's Test for Equality of Variances indicates homogeneity F= 4.150. Of referring to the statistical calculation result, it is observed that there is significant difference between the mean scores of pretest result of the experimental 
class when it is compared to their reading comprehension achievement posttest scores.

\section{CONCLUSION}

Considering the result of this present research, it is obvious that Jigsaw learning strategy was effective to improve EFL learners' reading ability. This statement was supported with the finding generated from statistical t-test results, showing that there is a significant difference in the posttest results between the mean scores of the experimental (71.68) and control class (67.95), in addition, it is also observed that the statistical sig. (2-tailed) t-test result indicates lower than 0.05 which is $\leq 0.048$.

\section{REFERENCES}

Adams, F. H. (2013). Using Jigsaw Technique as an Effective way of promoting cooperative Learning among primary Six Pupils in Fijai. International Journal of Education and Practice 1 (6): 64 - 74. Retrieved in 2014 from http://www.pakinsight.com/pdf-files/ijep1(6),64-74.pdf

Alma, B., \& Hurriyati, R. (2008). Manajemen Corporate Dan Strategi Pemasaran Jasa Pendidikan Fokus Pada Mutu Dan Layanan Prima. Bandung: Alfabeta.

Arikunto, Suharsimi. (2006). Prosedur Penelitian Suatu Pendekatan Praktik. Jakarta: PT Rineka Cipta.

Brisk, M. E., \& Harrington, M. M. (2000). Literacy and bilingualism: A handbook for all teachers. Mahwah, NJ: Lawrence Erlbaum Associates.

Cohen, Louis et.al. (2006). Research Methods in Education (Sixth Edition). New York: Croom Helm Ltd.

Mengduo and Xiaoling (2010). Jigsaw Strategy as a Cooperative Learning. Technique. Harbin Institute of Technology.

Solihatin, E., \& Raharjo. (2007). Cooperative Learning Analisis Model Pembelajaran IPS. Jakarta: Bumi Aksara.

Riyanto. (2010). Paradigma Baru Pembelajaran. Surabaya: Fajar Interpratama Offset. 


\title{
ROLE-PLAY AND SHOW-AND-TELL IN GRADE 5 STUDENTS' SPEAKING LEARNING
}

\author{
Choiril Anwar \\ Sultan Agung Islamic University \\ choirilanwar@unissula.ac.id
}

\begin{abstract}
This research aimed to investigate (1) the effectiveness of role-play and show-and-tell, and (2) which one was more effective between role-play and show-and-tell in grade 5 students' speaking learning. It was an experimental study by randomized pretest-posttest control group design. The data were collected by a non-test of an observation. The instrument of the research was observation sheets completed by speaking rubric on Likert scale. The data were analyzed by using one-way ANOVA followed by the Scheffe test. The results of the research showed that: (1) role-play and show-and-tell were effective in grade 5 students' speaking learning indicated by $p<0.05$ and; (2) role-play was more effective than show-andtell indicated by $p<0.05$.
\end{abstract}

Keywords: Speaking, Role-play, Show-and-tell

\section{INTRODUCTION}

Learning English is definitely urgent nowadays. English is important since it is a well known language and has frequently been referred to as a global language. It is the most commonly used language among foreign language speakers. Furthermore, it plays an important role in all aspects of society. It is the international language of diplomacy, banking, computing, medicine, business, science, technology, aviation and many other branches in today's society. English speakers are required at almost all departments or offices. Since this is a global language, when people with different languages come together they commonly use English to communicate one another. Therefore, learning and mastering it gives lots of advantages to the learner.

In Indonesia, as a foreign language, English is taught to students at almost all levels of education. At kindergarten and primary schools, students get English language as a local content or an extracuricular. At high schools, even 